\title{
Conscious Tourism's Dimension in the Historical Villages of Portugal
}

\author{
By Pedro Liberato ${ }^{1}$, Isabel Cerqueira ${ }^{2}$, Dália Liberato ${ }^{3}$
}

\begin{abstract}
Recent growth in the tourism sector has promoted the emergence of alternative types of tourism, such as rural tourism. Located in low-density territories, the Historical Villages of Portugal are one of the best examples regarding regional development from the perspective of sustainability. Although it is such an important topic today and gives longevity to destinations, its approach from the conscious tourism perspective is still little valued. This article discusses tourists' characteristics seeking Historical Villages, their behaviour, as well as their awareness and perception of the possible impacts they may cause. Intends to understand the perspective of the tourist experience in the Historical Villages region, and to ascertain the existence of conscious behaviours in rural destinations. Surveys were applied to 453 tourists of the Historical Villages. The main results obtained show that the sociodemographic profile influences the application of conscious practices, and the conscious tourist's attitude will contribute to the overall satisfaction concerning the destination. Also, the better the tourist's relationship with the destination and his overall satisfaction, the more likely he is to implement conscious practices. The results obtained should be evaluated by the regional DMOs with a view to implementing and developing conscious practices at these destinations.
\end{abstract}

Keywords: Rural Tourism, Conscious Tourism, Sustainability, Historical Villages

\section{Introduction}

Although rural tourism is still characterized as a small-scale activity, rural destinations are increasingly in vogue, in Portugal, combining the rural experience with the involvement in the natural environment. Inserted in the list of low-density territories, the network of Historical Villages of Portugal (rAHP) currently includes a set of 12 villages located in the NUTS II, Beiras and Serra da Estrela, Beira Baixa and Coimbra Region, and is distributed over 10 municipalities. Promoted by the Historical Villages of Portugal Association for Tourism Development (AHP-ADT), based in Belmonte, they bring together 12 destinations in one and have a wide and diversified tourist offer. The main objective is to make it a sustainable tourist destination, having therefore recently been awarded with the certificate of Biosphere Destination, the first networking destination in the world and the first at national level to receive this distinction. Also, the major route, referred as GR22, which links the 12 villages, received the Leading Quality Trails - Best of Europe label, becoming the "biggest European route" to win this certification in October 2019. After receiving the Biosphere Destination certificate in November 2018, the Historical 
Villages of Portugal obtained important recognition from the Responsible Tourism Institute (ITR). In this way, they achieve the leadership of the international community of Sustainable Tourism Destinations, first awarded in Portugal by the ITR.

Figure 1 shows the importance that the motivation "Nature and Rurality" assumes in the AHP, after the "Historical and Cultural Heritage".

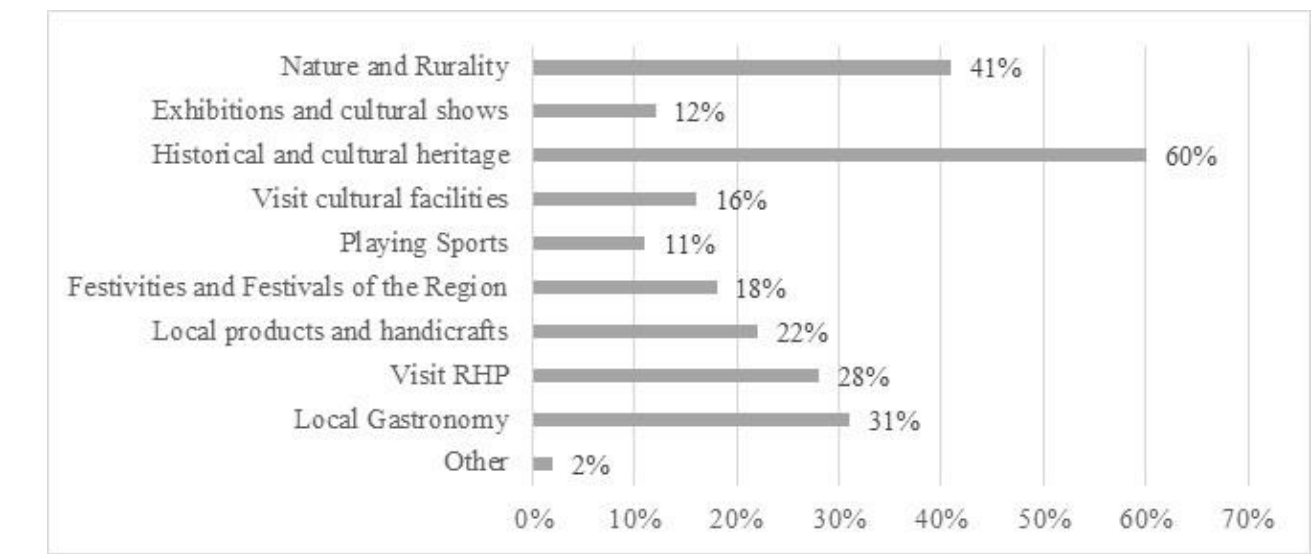

Figure 1- Motivations of AHP tourists

Source: [1] (Adapted)

As [2] state, recent trend of mass destination stagnation has led to the emergence of alternative types of tourism, such as rural tourism, strongly promoted by the institutions. Also, some loss of attractiveness of large cities due to factors such as pollution, stress and loneliness has led tourists to seek rural destinations where they can find tranquillity, peace, freedom, nature, re-encounter with traditions, among other attributes [3, 4]. Rural tourism has thus become a new and relevant factor in rural development, attracting tourist flows to rural areas and contributing to a better spatial and temporal distribution, improving the residents' quality of life in terms of infrastructure, employment, among other aspects [5]. This representativeness achieved by rural destinations, besides revealing notable positive consequences, also presents some concerns regarding its sustainability and responsiveness. Rural destinations will cease to be so, as they become mass destinations, so it is becoming increasingly important for tourists to be aware of preserving and respecting natural environments, while also promoting the local economy and culture. This is an indispensable situation in the good relationship between all the stakeholders, mainly local community, and tourists. This is why, in the last fifty years, several concerns have been raised about the impacts of human beings on the environment [6], so that sustainable tourism must be achieved, both from a supply perspective as [7] state, and tourist behaviour (demand) [8]. In an academic context there are several authors who seek to give an environmentally conscious profile based on certain characteristics of tourists $[9,10,11]$. Others are responsible for studying the behaviour of tourists, before and during their holidays, relating these same behaviours to several factors, such as the cost of acquiring products/services $[12,13,14]$, the level of knowledge about the impacts caused by tourism [15]. It is important to understand the behaviour of tourists on their holidays, but it is also 
important to understand whether this is conscious or coincidental [16], because sometimes we act in a certain way, simply because it is easier, cheaper or because it looks good in the eyes of those who are seeing or hearing us. Responsibility is an inseparable factor from sustainability [17] and therefore from Conscious Tourism [18].

The sustainability of rural territories, characterised by low density, also depends on the development of strategies based on their endogenous resources and the promotion of innovation dynamics associated with better use of resources [1]. Thus, it is important to highlight the Portuguese Strategy for Tourism 2027, with a strategic benchmark for tourism in Portugal by 2017-2027, and which aims to affirm the country as one of the most sustainable destinations in the world, with a cohesive, innovative, and competitive territory. Considering the 10 challenges proposed, must be highlighted "Sustainability" and "Tourism all year round", through the preservation and economic enhancement of cultural, natural, and rural heritage, not interfering with the life of the local community and promoting its protection, decreasing seasonality, extending the activity throughout the year, regarding the sustainability of destinations (Turismo de Portugal I.P., 2017). In the international context, the United Nations General Assembly defined, in 2015, the 2030 agenda for sustainable development, where the 17 Sustainable Development Goals (SDOs) emerge, with the respective objectives and targets through which the various agents of society should guide themselves [19].

To achieve the research purpose, two objectives and three hypotheses have been defined: Objective I - To interpret the factors that influence the environmentally conscious profile. Hypothesis 1 - Sociodemographic characteristics influence the application of conscious practices.

Objective II - To investigate how the relationship between the tourist and the surrounding environment encourages the practice of conscious behaviours.

Hypothesis 2 - The evaluation of the importance of certain behaviours in the destination is related to the activities carried out in the destination.

Hypothesis 3 - There is a relationship between the conscious attitude of the tourist and the degree of overall satisfaction in the destination.

This article begins with the literature review, linking the concepts of rural tourism, sustainable tourism, and conscious tourism, also highlighting the importance of the latter to give longevity to these territories. The second part describes the research methodology, the methodology for data collection, analysis, and discussion of results. The third and final part will present the conclusions of the study, and its relationship with the important role assumed by the regional Destination Management Organization (DMO) in the promotion and development of conscious practices in Historical Villages.

\section{Literature Review}

According to [20], rural tourism comes from the concept of rurality, associated with low population densities (small scale settlements, generally with less than 10,000 inhabitants), open spaces and contact with nature, heritage, traditional and sustainable societies, and practices, where its growth and development should contribute to the conservation and preservation of rural characteristics. Societies tend to traditionalism, where the influence of the past is often strong, and government policies lean towards 
conservation rather than radical or rapid change. The Portuguese Directorate General of Agriculture and Rural Development also defined Tourism in the Rural Area by its unique characteristics, by its capacity to recall practices, values, cultural and gastronomic traditions of rural regions. For [21], rural tourism is an activity in which the visitor's experience includes a set of products generally linked to nature, agriculture, rural ways of life and cultures, and visits to places of interest.

Rural tourism can also take on a spiritual dimension during the tourist experience because it is associated with tranquillity, escape from daily life and proximity to nature [22]. This segment represents the most Human side of Alternative Tourism, offering tourists the great opportunity to experience contact with different ways of living of communities, living in a rural environment, and calls for awareness of the respect and value of cultural identity. In this way, the tourist is, both an observer, and someone who actively integrates with the community during his stay because, as [23] state, it presupposes trips that have as a goal the realization of activities of coexistence and interaction with a rural community, in all aspects of daily life.

Considering tourism in rural space (TER), it becomes imperative to approach the concept from an integrated perspective, where tourism is linked to the economic, social, cultural, natural, and human structures of the localities where it occurs and develops in a sustainable way [24]. Tourism is synonymous with leisure, culture, mobility, and knowledge, but when not planned and managed according to the guidelines of sustainability, can generate negative impacts in the areas where it is developed, derived from its own success, putting at risk biodiversity, cultural heritage, local population, and endogenous resources [25]. Its negative consequences must be properly reversed and transformed into an industry of social, cultural, and environmental values. Ideally, a balanced and resilient long-term environmental, social and economic management should promote real attention to the needs of visitors, long-term environment protection, a sense of well-being and social identity of local residents, and prosperity from the economic point of view [26, 27]. For [1], it is essential to adopt strategies that focus on the use of the territories' endogenous resources and promote innovation dynamics related to the better management of these resources. The capacity to improve innovation in these areas is essential, as they have been going through periods of economic crisis, demographic and institutional changes, whether at the level of globalisation, decentralisation, or even the appearance on the market of new products and services, which pose not only major challenges but also opportunities [28]. [29], also suggest that tourist destinations require strategies to cope with change, and that resilience at its core offers a useful framework for developing new ways of planning and operating in uncertain times. Resilience in the tourism sector has been a growing concern in the academic context, and for [30] this ideal relies on the ability to adapt to circumstances, and indispensable for destinations to remain viable over time. Its relationship with sustainability is evident, but not linear, as destinations can be resilient without being sustainable, but cannot be sustainable without being resilient, assuming a necessary but not sufficient condition.

For [31], the concept of sustainable development is the inevitable result of social development that emphasises the coordinated development of society, economy, and nature, being also true for the sustainable development of rural tourism, which is based on a process of coordination between the rural economy, culture, and the environment. This 
concept became very popular mainly after the launch of the Brundtland Report [32], from which we can draw the following characteristics: responding to the present's needs without compromising the ability of future generations to meet their own needs; a process of change that considers the harmonization of the resources exploitation, the investments orientation, the techniques application and the institutions and companies development with the aim of strengthening socio-economic potential, capable of solving the needs and aspirations of humanity; the absence of an ideal model of sustainable development, due to the presence of several political-economic systems and ecological standards, since what remains constant is the search for a balance between human beings and the planet natural heritage. Its policies focus on three dimensions of sustainable development: economic, socio-cultural, and environmental sustainability. According to [33], sustainable development applies to all forms of tourism and destinations, including mass tourism and the main segments of niche tourism, being defined as "Tourism that considers its current and future economic, social and environmental impacts, meeting the needs of visitors, industry, the environment and the communities that receive them", governed by principles based on environmental, economic and socio-cultural aspects, calling for a balanced development of mentioned dimensions. [34], refers to sustainable development as a change process, reinforcing the need to support responsible development, where the traveller is preferred to the tourist, the individual to the group, and the specialised independent operator is more acceptable than large companies, local accommodation is preferable to hotels of international chains, i.e., the inverse of mass tourism. [35], name governance as another key factor for sustainable development. When personalised and effective, it can enhance democratic processes, provide guidance, and offer the means to make progress. A significant trend in tourism governance is its increasing emphasis on social learning, in which stakeholders share their knowledge, ideas and aspirations, and build new visions and action plans.

Ecotourism being one of the aspects of Sustainable Tourism and a positive alternative to mass tourism, promotes, in its essence, better resources management as well as important links between conservation and restoration [36]. However, it is important to address some of its weaknesses, due to the current existence of some ambiguity as to its true meaning or purpose. The International Ecotourism Society (TIES, 2015) defines ecotourism as "a responsible journey to natural areas that conserve the environment, sustain the well-being of local people and involve interpretation and education". Despite the efforts of the international scientific community, the term ecotourism still has an ambiguous meaning. Sustainable tourism and ecotourism are not synonymous, as many forms of ecotourism may not be sustainable, for ecotourism to contribute to sustainable development, careful management, commitment, and balance of interests are required [37]. Authors like [38] argue that some people have moved away from the ethical side of ecotourism, taking advantage of the concept to attract conservation conscious travellers to what are simply nature tourism programmes, which often generate negative environmental and social impacts, making the concept unworkable. [39] also argues that this type of tourism has been considered as a form of 'ego-tourism', because it does not actually present a solution to the masses, but by introducing new destinations, it adds a problem. [40], added the existence of an extensive development model, a common situation in rural tourism, which assumes that due to immature thinking and little knowledge, some entrepreneurs ignore 
ecological benefits in favour of economic benefits. They aggressively develop their lodgings, which provide agrotourism, gastronomic or even health experiences, directly or indirectly affecting the local community and the environment, damaging the relationship between tourists and locals. For [36], from the point of view of ecotourism in the context of rural tourism, there are no applicable standards and rules, nor qualified personnel, knowledge, and experience at the service of international and domestic tourists.

As [41] state, rural tourism will only be able to promote development if it follows a strategy that integrates local values and cultures. It is therefore relevant to implement an Integrated Rural Tourism (TRI), due to its more sustainable perspective, as it establishes networking links between social, cultural, economic, and environmental resources. TRI also promotes more holistic thinking, through the development of relationships between different local and regional resources, activities, products, and communities, based on trends in tourism demand [24]. For [42], the basic objective of TRI is to promote environmental, economic, and socio-cultural sustainability in tourism and to empower the local population and thus contribute to the sustainability of the entire rural system. However, although the TER has many advantages, it can also raise several problems. According to the [33], the impacts of tourism are mostly the result of social, economic, and cultural differences between the several actors involved. In order to minimise these problems, it is necessary to define alternatives or strategies for tourism development involving responsible use of territory, harmonising the interests of tourism, the environment and the local community [41]. It is in this follow-up that [33], have outlined some sustainable development goals integrated into public policies and Corporate Social Responsibility (CSR) actions. Integrated sustainability indicators for tourism (ISIT) also established tools for evaluating and monitoring sustainable development strategies [43]. In this way, sustainability indicators can lead to better decisions and more effective actions, simplifying, clarifying and aggregating available information for later policy formulation, while sharing ideas, thoughts and values from different stakeholder groups [44].

As [45] states, it is essential to promote a "humanization of tourism", consisting of a more ethical vision, in which the preservation of natural and cultural resources becomes a priority, together with the residents' quality of life, also giving rise to a more authentic and enriching tourist experience. According to [46], the negative consequences that human activity has on destinations may be due, both to a lack of environmental ethics, since tourists often do not transport their environmental beliefs into their behaviour as consumers, and when they are on holiday their main objective is to get to know the destination and the activities it offers, but also because often the destinations do not have the necessary conditions for them to transport their daily behaviour. A report from [47], found that about 55\% of global travellers report being more determined to make sustainable choices. Some additional conclusions could also be drawn from [46] research, namely that most tourists surveyed are unaware of the negative impacts that tourism activity has on the environment. In his perspective there are some factors identifying tourists who engage in this behaviour, such as age, nationality, qualifications, lifestyle, personal preferences, and attitudes. Considering their behaviour, tourists are aware of their activities' impacts on the environment and are somehow willing to change it, but only if it does not interfere with their holidays. Also [48] found that in a certain ecological tourism situation, tourists who applied "green" behaviours in their daily life, didn't do so when deciding on their trip, not understanding why it happens. Similarly 
[49] argued that holidays are taken for personal benefit, and changes in travel behaviour for environmental reasons are unlikely because tourists feel free from responsibility when on holiday. A possible explanation for these statements can be found in [50], as they claim that visitors may not be willing to change their behaviour if it interferes with pleasure or does not coincide with the trip objectives.

It is in Asunción-Paraguay, May 2011, with the XI Ibero-American Conference of Tourism Ministers, where it was presented for the first time the concept of Aware Tourism, unanimously approved, and included in the Joint Declaration signed by the tourism ministers and authorities of 23 Ibero-American countries and the World Tourism Organization [51]. Entrepreneurs, journalists, teachers, and other tourism agents took part in this concept presentation, with the aim of boosting this new trend. Also, UNWTO attaches great importance to the "love of the destination" as an integral and fundamental part of the conscious tourism concept, appearing as "a transforming life experience that generates personal growth and makes us better human beings". It contemplates the principles of sustainability and ethics, promotes peace, friendship and respect for love and life, focusing on tourism practice" [51]. It is a living and dynamic concept that encompasses responsibility, sustainability, the environment, and ethics, considered a giving and receiving experience [52]. Its ethical dimension is reflected in the relationship of equality, contact between human beings and societies. This complete and precise definition enhances the action, behaviour and responsibility assumed during the tourist experience. The main objective must be the coordination between all actors, favouring their cooperation [53, 54]. Conscious tourism can be considered as an evolution of sustainable tourism, since in addition to encompassing its economic, social, and environmental dimensions, adds the ethical dimension and can be applied to any type of tourism $[53,54,55]$. The UNWTO in its 2013 International Congress on Ethics and Tourism refers to ethics as a standard on which individuals base themselves to distinguish what is right from what is wrong, according to their values, and consists of something that guides them towards what is morally correct. The concept of Conscious Tourism complements and is in line with the Code of Ethics in Tourism, approved by the General Assembly of the World Tourism Organization in 1999, which provides a reference framework for responsible and sustainable development in a global context, aiming to foster the sector's benefits for communities and destinations, minimizing the negative impacts associated with the environmental and cultural dimension. The UNWTO II International Congress on Ethics and Tourism, considered that the construction of the tourism sector is a responsibility of everyone, from public institutions, the private sector, the local community, and tourists themselves. In this way, the Conscious Tourism is interpreted as a living concept based on principles such as equality and active participation, involving all agents.

In the specific case of the Historical Villages of Portugal, their classification as Historical Heritage has been contributing to the awareness of citizens about their importance and preservation. As [56] state, "it is fundamental that the social and cultural resources of the community are integrated in sustainable tourism projects, being themselves the drivers of development, since the authenticity and conservation of these social and cultural values are the guarantee of the success of tourism activity".

The general objectives of this study are to investigate the existence of conscious behaviours in the destination and, additionally, to understand the perspective of the tourist experience 
in the region covered by the Historical Villages.

As a first specific objective for this investigation, it is intended to interpret the factors that influence the environmentally conscious profile, through the formulation of an investigation hypothesis:

(H1): Sociodemographic characteristics influence the application of conscious practices.

Some studies already carried out in the field of conscious behaviours relate gender, age, beliefs, and travel characteristics to certain types of behaviour. Factors such as age, nationality, travel experience, values, attitudes, and knowledge influence conscious behaviour [46]. In the studies of [11, 9, 57], the profile of an environmentally conscious tourist can be attributed according to demographic characteristics and/or environmental attitudes/beliefs. [58] and [59] relate sustainable lifestyles and social practices to greater involvement in or understanding of pro-environmental practices. Even if tourists are aware of social and environmental problems, many resists changing their behaviour, which is partly due to the associated costs $[15,60]$. [14] considers that personal norms directly affect environmentally sustainable behaviour and develop if people are aware of environmental problems (awareness) and believe they are responsible for alleviating those problems (responsibility). Additionally, [16] divides sustainable behaviour into coincidental or intentional behaviour, where the first happens for other reasons, such as cost, and the intentional is carried out with the aim of minimizing negative environmental impacts.

The second specific objective of this research is to find out how the relationship between the tourist and the surrounding environment improves the experience at the destination and encourages the practice of conscious behaviours, through the formulation of two hypotheses of research:

(H2): The evaluation of the importance of certain behaviours at the destination is related to the activities carried out at the destination.

(H3): There is a relationship between the conscious attitude of the tourist and the degree of overall satisfaction at the destination.

Motivation and satisfaction are widely studied in the tourism literature, and for [61] the relevance of these elements results from their impact on tourist behaviour. Understanding the variables that moderate and determine satisfaction in tourism is extremely important in a highly competitive context with informed and increasingly demanding tourists. Previous authors studied the main motivations of tourists in Spain, such as the search for tranquillity, rest and contact with nature, as well as cultural or gastronomic character, and verified that individuals make different evaluations of certain factors, activities, and attributes of destination, depending on the relationship they have with what motivated or determined the trip. This fact allows the identification of a relationship between types of visitors classified according to their motives, and the evaluation of the elements that make up the tourist opportunities of the destination and the visitor's experience. Those where the main motivation was cultural, showed high levels of satisfaction regarding the opening hours of monuments and museums, guided tours, and the conservation of the monumental heritage. On the other hand, they have also found that certain elements strongly affect overall satisfaction and function independently of the reasons that led to the trip, aspects such as hospitality, quality of gastronomy, and availability of services and information. [40] also identified that tourist satisfaction is an important factor in assessing the main attractions. They considered that there is a gap in the development of rural 
tourism in certain regions, which compromises the individual tourist experience that is characteristic of rural tourism.

As we have seen before, it is very important to incorporate conscious behaviour into our daily life, but also during holidays. As [10] state, the involvement in pro-environmental behaviour decreases when we are on holiday. Some authors consider that outdoor activities can consist of possible healthier solutions to face the current "environmental health crisis" and thus contribute to a better understanding of nature, lead to more sustainable practices and, of course, enrich the tourist experience [12, 62, 63]. Nowadays, the tourist consumer is also looking for a more personalized service, and experiences linked to the authenticity of the traditions and customs of the destination, as well as leisure activities related to healthy practices and greater contact with nature. These trends have led destinations to adapt, with the emergence of new tourist modalities, such as cycling and hiking [64]. For the authors, these are important initiatives making the individual aware of the environment around him, thus tending to preserve it, and to contribute to its protection. Another aspect that could lead to the improvement of the tourist experience and, consequently, encourage the practice of conscious and responsible behaviour (recycling/reuse, energy saving) is the promotion of initiatives for sustainable development, either through the distribution of ecological products or the implementation of internal measures in some companies [65]. The management and adoption of sustainable tourism strategies and initiatives is one of the priorities for the economic and social development of destinations, becoming a key element in raising tourists' awareness and sensitizing about the impacts of the activity [3]. The physical environment also increases an individual's level of awareness, and this level of consciousness can lead to a significant experience [66]. [54] add the importance of tourism awareness in improving the tourist experience, for its capacity to contribute to the growth and personal enrichment of individuals, stating that the practical application of this behaviour triggers the "living well index". The authors also reinforce that, since this concept is based on principles such as equality and active participation of all individuals, where the involvement with the local communities and consequent reception by them prevails, and there is an involvement and respect for the cultural and natural heritage, an overvaluation of spiritual aspects instead of materials, contributing to the benefit of all stakeholders.

\section{Methodology}

This research addresses a new perspective of tourism, conscious tourism. Its objective is to perceive the development and implementation of conscious practices by tourists in the rAHP region. In this sense, this study employed a quantitative methodology, and the questionnaire survey was used as the method of data collection. which, according to [67], "consists of a research technique composed of a set of questions submitted to people in order to obtain information about knowledge, beliefs, feelings, values, interests, expectations, aspirations, fears, present or past behaviour, among others". The author also names several advantages inherent to this statistical method, of which we can highlight, the capacity to reach many people, guarantee their anonymity, impartiality, and flexibility at the time of filling. Before applying the questionnaire survey to our sample, and in accordance with [67], it was carried out a pre-test to check if there were any flaws in its wording or questions that were not suitable for our sample. For the investigation, the 
sampling technique used was random non-probability sampling, and the questionnaire was addressed to tourists who had visited the rAHP, to whom its confidentiality and anonymity were explained. Our survey is based on studies by $[57,11,58,9,15,12,62,63,58,59,61$, $57,10,16,14,66,40,68,16,60,64,3,11,46,65,54]$. The data was collected in August 2020 , obtaining a total of 453 valid surveys, which constitutes the total sample.

\section{Results}

In relation to the socio-demographic profile of the respondents, the data collected in Table 1, introduces the frequency and percentage of the total value of the sample.

Table 1- Sociodemographic characteristics

\begin{tabular}{|c|c|c|}
\hline Gender & Frequency & Percentage \\
\hline Female & 360 & $79,5 \%$ \\
\hline Male & 93 & $20,5 \%$ \\
\hline Age & Frequency & Percentage \\
\hline $17-25$ & 96 & $21,2 \%$ \\
\hline $26-35$ & 100 & $22,1 \%$ \\
\hline $36-45$ & 114 & $25,2 \%$ \\
\hline $46-55$ & 96 & $21,2 \%$ \\
\hline $56-65$ & 44 & $9,7 \%$ \\
\hline+65 & 3 & $0,7 \%$ \\
\hline Civil Status & Frequency & Percentage \\
\hline Married & 171 & $37,7 \%$ \\
\hline Single & 229 & $50,6 \%$ \\
\hline Unmarried couple & 17 & $3,8 \%$ \\
\hline Widow(er) & 4 & $0,9 \%$ \\
\hline Divorced & 32 & $7,1 \%$ \\
\hline Qualifications & Frequency & Percentage \\
\hline Basic Education & 11 & $2,4 \%$ \\
\hline High School & 118 & $26,0 \%$ \\
\hline Degree & 223 & $49,2 \%$ \\
\hline Post Degree & 101 & $22,3 \%$ \\
\hline Net Monthly Income & Frequency & Percentage \\
\hline Up to EUR 600 & 79 & $17,4 \%$ \\
\hline EUR 601 to EUR 1000 & 182 & $40,2 \%$ \\
\hline EUR 1001 to EUR 1500 & 117 & $25,8 \%$ \\
\hline EUR 1501 to EUR 2000 & 46 & $10,2 \%$ \\
\hline Over 2001 & 29 & $6,4 \%$ \\
\hline Country of Origin & Frequency & Percentage \\
\hline Portugal & 429 & 94,7 \\
\hline France & 5 & 1,1 \\
\hline Others (Europe) & 7 & 1,5 \\
\hline African countries & 7 & 1,5 \\
\hline Brazil & 3 & 0,7 \\
\hline Canada & 2 & 0,4 \\
\hline
\end{tabular}

Source: Own elaboration based on SPSS outputs 
The sample presents the following characteristics: $79.5 \%$ are female and the rest are male; $21 \%$ have between 17 and 25 years old, $22 \%$ have between 26 and 35 years old, $25 \%$ have between 36 and 45 years old, 21\% have between 46 and 55 years old, 10\% have between 56 and 65 years old, and less than $1 \%$ are over 65 years old; about $51 \%$ are single, $38 \%$ are married, $7 \%$ are divorced, $4 \%$ are unmarried couple; $49 \%$ have a degree, $26 \%$ have high school, $22 \%$ have post degree and $2 \%$ have only basic education; $40 \%$ have income between EUR 601 and EUR 1000, around 26\% between EUR 1001 and EUR 1500, 17\% up to EUR 600, 10\% between EUR 1501 and EUR 2000.

Considering the variable "Country of origin" it was possible to conclude that the predominant country of origin is Portugal, followed by France. In "Others (Europe)" Switzerland, The Netherlands, Moldova and Spain were grouped; in "African countries" Zimbabwe, Mozambique and Angola were grouped; finally, Brazil and Canada with only 3 and 2 elements (respectively).

Objective I - Interpret the factors that influence the environmentally conscious profile: H1 - Sociodemographic characteristics influence the application of conscious practices. The conscious practices considered in the questionnaire were related to three dimensions, namely "Attitude towards purchasing services/products": I'd rather pay more for a sustainable stay, I prefer to buy local products, even if they are more expensive, If there were economic incentives, I would opt for a more sustainable choice, I prefer to sleep at a local house because it is cheaper, and I prefer to sleep in a local house because of the experience; "Behaviour": Despite environmental problems, I don't worry when I go on holiday, I usually adopt "green" behaviour in my daily life, but I don't think about it when I go on holiday, and During my stay I am willing to reduce water, energy and/or waste consumption; "Knowledge": I am aware of the negative impacts of tourism activity, I consider important the existence of environmental certification standards, I seek guarantees of sustainability in destinations. The following analysis, with reference to H1, only summarizes the statistically significant relationships between the dimensions under analysis and socio-demographic characteristics.

The methods used for the H1 assessment were the t-test, a multi-factor ANOVA, and a Kruskal-Wallis one-way ANOVA. The t-Student parametric test is only considered if the study groups are large, and is used to analyse a quantitative variable, in percentage or ordinal on the Likert scale, both through analysis of the hypotheses [75]. When study groups can be considered large, the parametric ANOVA test is used to study the relationship between an ordinal variable on the Likert scale and a qualitative variable which tests the hypotheses [75]. When there are small groups in comparison, the assumption of normality is not verified, and instead of the ANOVA a non-parametric Kruskal-Wallis test must be applied [75]. 
Table 2- Relationship between the application of conscious practices and gender

\begin{tabular}{|c|c|c|c|c|c|c|}
\hline & Gender & $\mathrm{N}$ & Average & $\begin{array}{l}\text { Standard } \\
\text { Deviation }\end{array}$ & $\mathrm{T}$ & $\mathrm{p}$ \\
\hline \multirow{2}{*}{ I would rather pay more for a sustainable stay } & Female & 360 & 3,11 & 1,117 & \multirow[t]{2}{*}{1,969} & \multirow[t]{2}{*}{$* 0,050$} \\
\hline & Male & 93 & 2,85 & 1,122 & & \\
\hline \multirow{2}{*}{$\begin{array}{l}\text { I prefer to buy local products, even if they are } \\
\text { more expensive }\end{array}$} & Female & 360 & 3,52 & 1,081 & \multirow[t]{2}{*}{2,668} & \multirow[t]{2}{*}{$* * 0,008$} \\
\hline & Male & 93 & 3,17 & 1,256 & & \\
\hline \multirow{2}{*}{$\begin{array}{l}\text { Despite the environmental problems, I don't } \\
\text { worry when I go on holiday }\end{array}$} & Female & 360 & 1,47 & 0,975 & \multirow[t]{2}{*}{$-3,081$} & \multirow[t]{2}{*}{$* * 0,002$} \\
\hline & Male & 93 & 1,84 & 1,254 & & \\
\hline \multirow{2}{*}{$\begin{array}{l}\text { I usually adopt "green" behaviour in my daily life, } \\
\text { but I don't think about it when I go on holiday }\end{array}$} & Female & 360 & 1,59 & 1,068 & \multirow[t]{2}{*}{$-2,622$} & $* * 0,009$ \\
\hline & Male & 93 & 1,92 & 1,262 & & \\
\hline
\end{tabular}

Table 2 presents the statistically significant relationships between the application of genderconscious practices. There is a significant agreement between the female gender in the statements "I prefer to pay more for a sustainable stay" and "I prefer to buy local products, even if they are more expensive", with the statements "Despite environmental problems, I don't worry when I go on holiday" and "I usually adopt green behaviours in my day-today life, but I don't think about it when I go on holiday", the highest degree of agreement concerns the male gender.

Table 3- Relationship between the application of conscious practices and age

\begin{tabular}{lcccccc}
\hline & Age & $\mathrm{N}$ & Average & Standard Deviation & $\mathrm{F}$ & $\mathrm{p}$ \\
\hline If there were economic incentives, & $17-25$ & 96 & 4,07 & 1,049 & $3,9966^{* * 0,001}$ \\
I would opt for a more & $26-35$ & 100 & 4,10 & 1,000 & \\
sustainable choice & $36-45$ & 114 & 3,87 & 1,000 & \\
& $46-55$ & 96 & 3,76 & 1,054 & \\
& $56-65$ & 44 & 3,41 & 1,168 & \\
& +65 & 3 & 3,00 & 2,000 & \\
\hline I am aware of the negative & $17-25$ & 96 & 3,71 & 1,169 & $3,910 * * 0,002$ \\
impacts of tourism activity & $26-35$ & 100 & 3,64 & 1,078 & \\
& $36-45$ & 114 & 3,46 & 1,256 & \\
& $46-55$ & 96 & 3,06 & 1,177 & \\
& $56-65$ & 44 & 3,23 & 1,179 & \\
& +65 & 3 & 3,00 & 2,000 & \\
\hline
\end{tabular}

Table 3 presents the statistically significant relationships between the application of conscious practices and age. In the statement "If there were economic incentives, I would opt for a more sustainable choice" there is an increase in class agreement from 17-25 to 26-35, which subsequently decreases with age. In the statement "I am aware of the negative impacts of tourism activity", there is a decrease in age agreement. 
Table 4- Relationship between the application of conscious practices and civil status

\begin{tabular}{llcccc}
\hline & Civil Status & N & Average & $\begin{array}{c}\text { Standard } \\
\text { Deviation }\end{array}$ & F \\
\hline If there were economic incentives, Married & 171 & 3,79 & 1,069 & $3,698^{* *} 0,006$ \\
I would opt for a more sustainable Single & 229 & 4,00 & 1,049 & \\
choice & Unmarried couple & 17 & 4,00 & 1,061 & \\
& Widow(er) & 4 & 2,25 & 0,957 & \\
& Divorced & 32 & 3,75 & 0,950 & \\
\hline I am aware of the negative & Married & 171 & 3,26 & 1,161 & $3,345 * * 0,010$ \\
impacts of tourism activity & Single & 229 & 3,62 & 1,169 & \\
& Unmarried couple & 17 & 3,53 & 1,179 & \\
& Widow(er) & 4 & 2,50 & 1,000 & \\
& Divorced & 32 & 3,19 & 1,447 & \\
\hline
\end{tabular}

Source: Own elaboration based on SPSS outputs $\quad{ }^{*} p<0.05^{* *} p<0.01$

Table 4 presents the statistically significant relationships between the application of conscious practices and civil status. We find that those who would be willing to have more sustainable choices if there were economic incentives and more, demonstrate their knowledge of the impacts of tourism activity, in descending order, are single, unmarried, married and divorced.

Table 5- Relationship between the application of conscious practices and qualifications

Qualifications N Average Standard F p

Deviation

\begin{tabular}{|c|c|c|c|c|c|}
\hline \multirow{4}{*}{$\begin{array}{l}\text { I'd rather pay more for a } \\
\text { sustainable stay }\end{array}$} & Basic Education & 11 & 2,27 & 1,009 & \multirow{4}{*}{$3,079 * 0,027$} \\
\hline & High School & 118 & 2,91 & 1,046 & \\
\hline & Degree & 223 & 3,12 & 1,121 & \\
\hline & Post Degree & 101 & 3,17 & 1,184 & \\
\hline \multirow{4}{*}{$\begin{array}{l}\text { I prefer to buy local products, } \\
\text { even if they are more expensive }\end{array}$} & Basic Education & 11 & 2,55 & 1,214 & \multirow[t]{4}{*}{$5,241 * * 0,001$} \\
\hline & High School & 118 & 3,23 & 1,128 & \\
\hline & Degree & 223 & 3,52 & 1,090 & \\
\hline & Post Degree & 101 & 3,63 & 1,129 & \\
\hline \multirow{4}{*}{$\begin{array}{l}\text { If there were economic incentives } \\
\text { I would opt for a more sustainable } \\
\text { choice }\end{array}$} & Basic Education & 11 & 3,55 & 1,036 & \multirow[t]{4}{*}{$9,117 * * 0,000$} \\
\hline & High School & 118 & 3,48 & 1,027 & \\
\hline & Degree & 223 & 4,03 & 1,006 & \\
\hline & Post Degree & 101 & 4,09 & 1,105 & \\
\hline \multirow{4}{*}{$\begin{array}{l}\text { I am aware of the negative } \\
\text { impacts of tourism activity }\end{array}$} & Basic Education & 11 & 2,45 & 0,820 & \multirow[t]{4}{*}{$4,098 * * 0,007$} \\
\hline & High School & 118 & 3,27 & 1,174 & \\
\hline & Degree & 223 & 3,53 & 1,150 & \\
\hline & Post Degree & 101 & 3,55 & 1,307 & \\
\hline \multirow{4}{*}{$\begin{array}{l}\text { I consider important the existence } \\
\text { of environmental certification } \\
\text { standards }\end{array}$} & Basic Education & 11 & 3,64 & 0,924 & \multirow[t]{4}{*}{$4,002 * * 0,008$} \\
\hline & High School & 118 & 3,81 & 0,987 & \\
\hline & Degree & 223 & 4,12 & 0,944 & \\
\hline & Post Degree & 101 & 4,17 & 0,949 & \\
\hline
\end{tabular}

Source: Own elaboration based on SPSS outputs $\quad{ }^{*} p<0.05 * * p<0.01$

Table 5 presents the statistically significant relationships between the application of conscious 
practices and qualifications. We find that there is an increase in knowledge with the increase in the level of qualifications, except in agreement with the statement "If there were economic incentives, I would opt for a more sustainable choice" in which there is a decrease from Basic to High School.

Table 6- Relationship between the application of conscious practices and individual net income

\begin{tabular}{lcccccc}
\hline & $\begin{array}{c}\text { Net Monthly } \\
\text { Income }\end{array}$ & N & Average & $\begin{array}{c}\text { Standard } \\
\text { Deviation }\end{array}$ & KW & p \\
\hline I prefer to buy local & Up to EUR 600 & 79 & 3,16 & 1,091 & 9,779 & $* 0,044$ \\
products, even if they & EUR 601 to EUR 1000 & 182 & 3,52 & 1,106 & \\
are more expensive & EUR 1001 to EUR 1500 & 117 & 3,41 & 1,100 & \\
& EUR 1501 to EUR 2000 & 46 & 3,50 & 1,243 & \\
& Over 2001 & 29 & 3,83 & 1,167 & \\
\hline I usually adopt "green" & Up to EUR 600 & 79 & 1,99 & 1,344 & $9,558 * 0,049$ \\
behaviour in my daily life, & EUR 601 to EUR 1000 & 182 & 1,62 & 1,080 & \\
but I don't think about it & EUR 1001 to EUR 1500 & 117 & 1,56 & 1,021 & \\
when I go on holiday & EUR 1501 to EUR 2000 & 46 & 1,70 & 1,152 & \\
& Over 2001 & 29 & 1,34 & 0,814 & \\
\hline
\end{tabular}

Source: Own elaboration based on SPSS outputs ${ }^{*} p<0.05{ }^{* *} p<0.01$

Table 6 presents the statistically significant relationships between the application of conscious practices and individual net monthly income. With individual net monthly income up to 1000 euros there is an increase in agreement on the purchase of local products, even if they are more expensive. This decreases from EUR 1001 to EUR 1500 and increases again from EUR 1501 to over EUR 2001. Considering the statement "I usually adopt green behaviour in my day-to-day life, but I don't think about it when I go on holiday", we see a decrease in the agreement for individual net monthly income up to EUR 1500, followed by an increase between EUR 1501 and EUR 2000.

Singles and unmarried couples are the most representative individuals, demonstrating the greatest knowledge about the impacts of tourism activity. Also, in general, the higher the level of qualifications, the better the conscious attitude and knowledge towards the application of conscious practices. Income influences the decision to buy local products, except for the range between 1001 euros and 1500 euros. [72] reinforce the significant impact that income inequalities have on sustainable development, bringing to their study the importance of the United Nations' Sustainability Goals, which should be considered a basis for implementing environmental protection measures through inclusive growth and reducing inequalities.

Objective II - To investigate how the relationship between the tourist and the surrounding environment encourages the practice of conscious behaviours.

H2 - The evaluation of the importance of certain behaviours at the destination is related to the activities carried out at the destination.

The Pearson coefficient [75] is used to study the relationship between quantitative variables resulting from ordinal scales or Likert scales, by measuring the association between -1 and 1 . The closer it is to extreme values, the greater the association between the variables. The absolute value of the correlation indicates the intensity of the 
association. [75] considers correlations to be weak when the absolute value of $r(|r|)$ is below 0,25 and moderate to $0,25 \leq|r|<0,5$; they are strong to $0,5 \leq|r|<0,75$.

Table 7 - Relations between behaviour at destination and activities carried out at destination

$\begin{array}{ccc}\begin{array}{c}\text { Purchase } \\ \text { of local } \\ \text { products }\end{array} & \begin{array}{c}\text { Meals at } \\ \text { the local } \\ \text { restaurant }\end{array} & \begin{array}{c}\text { Bicycle } \\ \text { travel }\end{array} \\ & \end{array}$

\begin{tabular}{|c|c|c|c|c|c|c|c|}
\hline \multirow{3}{*}{$\begin{array}{l}\text { Visit the Historical } \\
\text { Centre }\end{array}$} & & & & & containers & & culture \\
\hline & $\mathrm{r}$ & $0,330^{* *}$ & $0,378^{* *}$ & 0,013 & $0,323^{* *}$ & $0,247^{* *}$ & $0,411^{* *}$ \\
\hline & $\mathrm{p}$ & 0,000 & 0,000 & 0,783 & 0,000 & 0,000 & 0,000 \\
\hline \multirow{2}{*}{$\begin{array}{l}\text { Visit the main } \\
\text { tourist attractions }\end{array}$} & $\mathrm{r}$ & $0,234^{* *}$ & $0,345^{* *}$ & 0,004 & $0,272^{* *}$ & $0,189^{* *}$ & $0,320^{* *}$ \\
\hline & $\mathrm{p}$ & 0,000 & 0,000 & 0,929 & 0,000 & 0,000 & 0,000 \\
\hline \multirow[t]{2}{*}{ Bicycle touring } & $\mathrm{r}$ & 0,070 & 0,029 & $0,334^{* *}$ & $-0,002$ & $0,111^{*}$ & $-0,031$ \\
\hline & $\mathrm{p}$ & 0,137 & 0,544 & 0,000 & 0,962 & 0,018 & 0,515 \\
\hline \multirow[t]{2}{*}{ Canoeing } & $\mathrm{r}$ & $0,110^{*}$ & 0,060 & $0,314^{* *}$ & 0,045 & 0,092 & 0,016 \\
\hline & $\mathrm{p}$ & 0,019 & 0,200 & 0,000 & 0,341 & 0,052 & 0,726 \\
\hline \multirow[t]{2}{*}{ River beaches } & $\mathrm{r}$ & $0,159^{* *}$ & $0,170^{* *}$ & $0,167^{* *}$ & $0,107^{*}$ & $0,172^{* *}$ & $0,118^{*}$ \\
\hline & $\mathrm{p}$ & 0,001 & 0,000 & 0,000 & 0,023 & 0,000 & 0,012 \\
\hline \multirow{2}{*}{$\begin{array}{l}\text { Mountain bike } \\
\text { routes }\end{array}$} & $\mathrm{r}$ & 0,082 & 0,053 & $0,374^{* *}$ & 0,003 & $0,121^{* *}$ & $-0,010$ \\
\hline & $\mathrm{p}$ & 0,080 & 0,265 & 0,000 & 0,951 & 0,010 & 0,831 \\
\hline \multirow[t]{2}{*}{ Walking trails } & $\mathrm{r}$ & $0,258^{* *}$ & $0,185^{* *}$ & $0,330^{* *}$ & $0,150^{* *}$ & $0,207^{* *}$ & $0,215^{* *}$ \\
\hline & $\mathrm{p}$ & 0,000 & 0,000 & 0,000 & 0,001 & 0,000 & 0,000 \\
\hline \multirow{2}{*}{$\begin{array}{l}\text { Involvement with } \\
\text { the local community }\end{array}$} & $\mathrm{r}$ & $0,277^{* *}$ & $0,233^{* *}$ & $0,216^{* *}$ & $0,171^{* *}$ & $0,521^{* *}$ & $0,233^{* *}$ \\
\hline & $\mathrm{p}$ & 0,000 & 0,000 & 0,000 & 0,000 & 0,000 & 0,000 \\
\hline \multirow{2}{*}{$\begin{array}{l}\text { Learning to make } \\
\text { handicrafts }\end{array}$} & $\mathrm{r}$ & $0,119^{*}$ & 0,038 & $0,241^{* *}$ & 0,014 & $0,227^{* *}$ & 0,034 \\
\hline & $\mathrm{p}$ & 0,011 & 0,418 & 0,000 & 0,774 & 0,000 & 0,467 \\
\hline \multirow[t]{2}{*}{ Wildlife observation } & $\mathrm{r}$ & $0,219^{* *}$ & $0,172^{* *}$ & $0,213^{* *}$ & $0,135^{* *}$ & $0,236^{* *}$ & $0,183^{* *}$ \\
\hline & $\mathrm{p}$ & 0,000 & 0,000 & 0,000 & 0,004 & 0,000 & 0,000 \\
\hline \multirow{2}{*}{$\begin{array}{l}\text { Activities for the } \\
\text { conservation of } \\
\text { natural resources }\end{array}$} & $\mathrm{r}$ & $0,208^{* *}$ & $0,166^{* *}$ & $0,226^{* *}$ & $0,141^{* *}$ & $0,322^{* *}$ & $0,131^{* *}$ \\
\hline & $\mathrm{p}$ & 0,000 & 0,000 & 0,000 & 0,003 & 0,000 & 0,005 \\
\hline
\end{tabular}

Source: Own elaboration based on SPSS outputs ${ }^{*} p<0.05^{* *} p<0.01$

According to table 7 the results indicate that those who carry out the listed activities most often attach greater importance to related behaviours. As there are moderate and strong correlations, H2 is observed. Moderate correlations were found between those who value activities such as visiting the historic centre, and purchase of local products, meals at local restaurant, placing rubbish in appropriate containers, relationship with the local community and respect for local habits and culture; visit the main tourist attractions and meals at the local restaurant, placing rubbish in appropriate containers, relationship with the local community, and respect for local habits and culture; also between canoeing, mountain bike routes and walking trails with bicycle travel. There is a strong correlation between those who value "Involvement with the local community" and the appreciation of the relationship with the local community as the main behaviour.

H3 - There is a relationship between the conscious attitude of the tourist and the degree of overall satisfaction in the destination. 
Table 8 - Relationship between attitude towards services/products and overall destination satisfaction

\begin{tabular}{|c|c|c|c|c|c|c|}
\hline & & $\begin{array}{l}\text { I'd rather pay } \\
\text { more for a } \\
\text { sustainable } \\
\text { stay }\end{array}$ & $\begin{array}{l}\text { I prefer to buy } \\
\text { local products, } \\
\text { even if they are } \\
\text { more expensive }\end{array}$ & $\begin{array}{c}\text { If there were } \\
\text { economic } \\
\text { incentives, I would } \\
\text { opt for a more } \\
\text { sustainable choice }\end{array}$ & $\begin{array}{l}\text { I prefer to } \\
\text { sleep in a } \\
\text { local house } \\
\text { because it is } \\
\text { cheaper }\end{array}$ & $\begin{array}{l}\text { I prefer to sleep } \\
\text { in a local house } \\
\text { because of the } \\
\text { experience }\end{array}$ \\
\hline \multirow{2}{*}{\multicolumn{2}{|c|}{$\begin{array}{l}\text { I am satisfied with } \\
\text { the quality of the } \\
\text { offer at destination }\end{array}$}} & $0,306^{* *}$ & $0,278^{* *}$ & $0,246^{* *}$ & $0,181 * *$ & $0,190^{* *}$ \\
\hline & & 0,000 & 0,000 & 0,000 & 0,000 & 0,000 \\
\hline \multirow{2}{*}{$\begin{array}{l}\text { Destination has } \\
\text { exceeded my } \\
\text { expectations }\end{array}$} & $\mathrm{r}$ & $0,285 * *$ & $0,283 * *$ & $0,218^{* *}$ & $0,192 * *$ & $0,223 * *$ \\
\hline & $\mathrm{p}$ & 0,000 & 0,000 & 0,000 & 0,000 & 0,000 \\
\hline \multirow{2}{*}{$\begin{array}{l}\text { I will recommend } \\
\text { the Historical } \\
\text { Villages to my } \\
\text { friends and family }\end{array}$} & $\mathrm{r}$ & $0,309 * *$ & $0,316^{* *}$ & $0,315^{* *}$ & $0,186^{* *}$ & $0,260 * *$ \\
\hline & $\mathrm{p}$ & 0,000 & 0,000 & 0,000 & 0,000 & 0,000 \\
\hline \multirow{2}{*}{$\begin{array}{l}\text { I intend to visit the } \\
\text { destination in the } \\
\text { next } 3 \text { years }\end{array}$} & & $0,237^{* *}$ & $0,225^{* *}$ & $0,217 * *$ & $0,199 * *$ & $0,310 * *$ \\
\hline & $\mathrm{p}$ & 0,000 & 0,000 & 0,000 & 0,000 & 0,000 \\
\hline
\end{tabular}

Source: Own elaboration based on SPSS outputs

${ }^{*} p<0.05 * * p<0.01$

Table 8 shows the statistically significant relationships between the attitude towards services/products and overall destination satisfaction. The results indicate that those with the greatest agreement on each of the aspects listed are most likely to practice the attitudes related to them. Moderate correlations were found, as example, between the attitudes "I'd rather pay more for a sustainable stay", "I prefer to buy local products, even if they are more expensive", "If there were economic incentives, I would opt for a more sustainable choice", "I prefer to sleep in a local house because of the experience", and "I will recommend the Historical Villages to my friends and family"; also between "I prefer to sleep in a local house because of the experience" and "I intend to visit the destination in the next 3 years".

Table 9 - Relations between the dimension's behaviour in relation to the application of conscious practices and global satisfaction of destination

\begin{tabular}{|c|c|c|c|}
\hline & $\begin{array}{c}\text { Despite the } \\
\text { environmental problems, } \\
\text { I don't worry when I go } \\
\text { on holiday }\end{array}$ & $\begin{array}{l}\text { I usually adopt "green" } \\
\text { behaviour in my daily life, } \\
\text { but I don't think about it } \\
\text { when I go on holiday }\end{array}$ & $\begin{array}{l}\text { During my stay I am } \\
\text { willing to reduce water, } \\
\text { energy and/or waste } \\
\text { consumption }\end{array}$ \\
\hline $\begin{array}{l}\text { I am satisfied with the } \\
\text { quality of the offer at } \\
\text { destination }\end{array}$ & $\begin{array}{lc}\mathrm{r} & 0,101^{*} \\
\mathrm{p} & 0,031\end{array}$ & $\begin{array}{c}0,178^{* *} \\
0,000\end{array}$ & $\begin{array}{c}0,276^{* *} \\
0,000\end{array}$ \\
\hline $\begin{array}{l}\text { Destination has } \\
\text { exceeded my } \\
\text { expectations }\end{array}$ & $\begin{array}{c}0,114^{*} \\
0,015\end{array}$ & $\begin{array}{c}0,127 * * \\
0,007\end{array}$ & $\begin{array}{c}0,272^{* *} \\
0,000\end{array}$ \\
\hline $\begin{array}{l}\text { I will recommend the } \\
\text { Historical Villages to } \\
\text { my friends and family }\end{array}$ & $\begin{array}{r}-0,065 \\
0,164\end{array}$ & $\begin{array}{l}-0,002 \\
0,972\end{array}$ & $\begin{array}{c}0,343 * * \\
0,000\end{array}$ \\
\hline $\begin{array}{l}\text { I intend to visit the } \\
\text { destination in the next }\end{array}$ & $\begin{array}{l}0,000 \\
0,998\end{array}$ & $\begin{array}{c}-0,026 \\
0,583\end{array}$ & $\begin{array}{c}0,258^{* *} \\
0,000\end{array}$ \\
\hline
\end{tabular}

3 years

Source: Own elaboration based on SPSS outputs $\quad{ }^{*} p<0.05 * * p<0.01$ 
Table 9 shows statistically significant relationships between behaviour in relation to the application of conscious practices and overall destination satisfaction, highlighting the moderate correlation between "During my stay I am willing to reduce water, energy and/or waste consumption and "I will recommend the Historical Villages to my friends and family".

Table 10 - Relations between the knowledge dimensions regarding the application of conscious practices and global destination satisfaction

\begin{tabular}{|c|c|c|c|c|}
\hline & & $\begin{array}{l}\text { I am aware of the } \\
\text { negative impacts } \\
\text { of tourism activity }\end{array}$ & $\begin{array}{l}\text { I consider important the } \\
\text { existence of environmental } \\
\text { certification standards }\end{array}$ & $\begin{array}{l}\text { I seek guarantees of } \\
\text { sustainability in } \\
\text { destinations }\end{array}$ \\
\hline \multirow{2}{*}{$\begin{array}{l}\text { I am satisfied with the } \\
\text { quality of the offer at } \\
\text { destination }\end{array}$} & $\mathrm{r}$ & $0,258^{* *}$ & $0,267 * *$ & $0,304 * *$ \\
\hline & $\mathrm{p}$ & 0,000 & 0,000 & 0,000 \\
\hline \multirow{2}{*}{$\begin{array}{l}\text { Destination has } \\
\text { exceeded my } \\
\text { expectations }\end{array}$} & $\mathrm{r}$ & $0,182 * *$ & $0,246^{* *}$ & $0,239 * *$ \\
\hline & $\mathrm{p}$ & 0,000 & 0,000 & 0,000 \\
\hline \multirow{2}{*}{$\begin{array}{l}\text { I will recommend the } \\
\text { Historical Villages to my } \\
\text { friends and family }\end{array}$} & $\mathrm{r}$ & $0,289^{* *}$ & $0,428^{* *}$ & $0,360^{* *}$ \\
\hline & $\mathrm{p}$ & 0,000 & 0,000 & 0,000 \\
\hline \multirow{2}{*}{$\begin{array}{l}\text { I intend to visit the } \\
\text { destination in the next } 3 \\
\text { years }\end{array}$} & $\mathrm{r}$ & 0,191 ** & $0,295^{* *}$ & $0,294 * *$ \\
\hline & $\mathrm{p}$ & 0,000 & 0,000 & 0,000 \\
\hline
\end{tabular}

Source: Own elaboration based on SPSS outputs $\quad{ }^{*} p<0.05{ }^{* *} p<0.01$

Table 10 presents the statistically significant relationships between knowledge regarding the application of conscious practices and overall destination satisfaction. Should be noted as moderate correlations, the relationship between "I consider important the existence of environmental certification standards", and "I seek guarantees of sustainability in destinations", with "I will recommend the Historical Villages to my friends and family".

\section{Conclusions}

The role assumed by rural destinations has changed in recent decades because of the emergence of new forms of tourism, the valorisation and development of these territories by public and private entities [2], and by following the new trends in consumer behaviour, which increasingly seek authentic experiences, tranquillity, and value activities in contact with nature and local communities [4, 22]. This new dynamic, attributed to territories characterised by the phenomenon of low density, requires some attention from institutions, not only from the point of view of supply but also of demand. It is crucial to meet the premises of Conscious Tourism, an innovative concept in which the "love of destination" is valued, and which can be understood as an evolution of Sustainable Tourism, because in addition to encompassing the economic, social, and environmental dimensions of sustainable tourism, it adds the ethical dimension $[53,54,55]$.

Regarding the influence that socio-demographic characteristics have on the implementation of conscious practices, [69] corroborated previous studies when they concluded that women assume stronger environmental attitudes and behaviours than men. 
This theory is based on the process of socialization of women, which is more directed towards the "ethics of care", as other studies already concluded. The same happened with hypothesis 1 , since the female gender shows more awareness, as it does not mind spending more for a sustainable stay, or local products, while the male gender claims to have environmental concerns and put them into practice in daily life, however, when on holiday it does not assume these behaviours. In general, it was found that younger people have more concerns about the application of conscious practices, which may be in line with the results of the [70] report, in which the younger participants demonstrated that not only climate change but also the degradation of nature are among the most serious global problems. However, it should be noted that new generations are more likely to travel by air, contributing to the emission of greenhouse gases, counteracting the trend among younger tourists considered more environmentally conscious [71]. The authors reinforce the idea that although people develop sustainable practices in their daily lives, they are not transported to their destination, they even suggest that the change in behaviour lies in rethinking the concept of what is a 'sustainable lifestyle'.

Regarding hypothesis 2 and 3, results show that, in general, when the tourist implements conscious practices in the destination, he assumes greater global satisfaction, the same can happen in the opposite direction, i.e., the involvement of the tourist during the tourist experience can also positively influence his attitudes and conscious practices. Although less evident, it has been found that some people who do not adopt conscious behaviours at their destination are satisfied with the quality of the offer and admit that it has exceeded their expectations. However, the results highlight that when tourists do not engage in conscious behaviour in the destination, there is no evidence of loyalty towards it. Achieving tourist satisfaction is one of the most important objectives in managing a tourism destination [73], however it is a goal that depends on several factors, from which we highlight the tourist's expectations. As [74] states, satisfaction is a subjective opinion based on the tourist's assessment after experiencing different experiences in the destination; in this sense, the tourist's satisfaction is essentially what the tourist expects from it. It is in this follow-up that the tourist's conscious attitude assumes influence on the destination overall satisfaction, since it considers that the tourist as a consumer, has a superior sensitivity, the capacity to put himself in the other's place, feels a "love of the destination", and as the [51] states, conscious tourism consists of an experience of giving and receiving. On the other hand, the better the tourist's relationship with the destination and his overall satisfaction, the more likely he is to implement conscious practices. It would be interesting to consider a deeper approach to this aspect from the perspective of the regional DMOs, and even in a national context, in a strategic perspective of improving tourism supply, training and capacity building for all stakebolders, regarding the development and promotion of conscious tourism.

\section{Acknowledgements}

The authors thank the support of the Portuguese Foundation for the Development of Science and Technology (FCT), through the "Summer with Science" Project, and CiTUR, R\&D unit funded by the FCT - Portuguese Foundation for the Development of Science and Technology, Ministry of Science, Technology and Higher 
Education, under the scope of the project UID/BP/04470/2020.

\section{References}

[1] Melo, A. I., Marques, R. P., Ferreira, A., Santos, C., Dias, D., Gomes, G., Azevedo, G., Natário, M., Rocha, P., Biscaia, R., \& Duarte, R. (2020). Projeto PlowDeR: Relatório Final (6 ${ }^{\text {th }}$ Ed.). UA Editora.

[2] Wondirad, A., Tolkach, D., \& King, B. (2020). Stakeholder collaboration as a major factor for sustainable ecotourism development in developing countries. Tourism Management, 78, 104024. https://doi.org/10.1016/j.tourman.2019.104024

[3] Orlando, S. (2003). TERN: Turismo em espaços rurais e naturais. IPC: Instituto Politécnico de Coimbra.

[4] Sharpley, R. (1996). Tourism and Leisure in the Countryside (2nd ed.). ELM Publications.

[5] Campón-Cerro, A. M., Hernández-Mogollón, J. M., \& Alves, H. (2017). Sustainable improvement of competitiveness in rural tourism destinations: The quest for tourist loyalty in Spain. Journal of Destination Marketing \& Management, 6(3), 252-266. https://doi.org/10.1016/j.jdmm.2016.04.005

[6] Hanna, P., Wijesinghe, S., Paliatsos, I., Walker, C., Adams, M., \& Kimbu, A. (2019). Active engagement with nature: Outdoor adventure tourism, sustainability and wellbeing. Journal of Sustainable Tourism, 27(9), 1355-1373. https://doi.org/10.1080/09669582.2019.1621883

[7] Hawkins, R., \& Middleton, V. (1998). Sustainable Tourism: A Marketing Perspective. Routledge.

[8] Dolnicar, S., Crouch, G. I., \& Long, P. (2008). Environment-friendly Tourists: What Do We Really Know About Them? Journal of Sustainable Tourism, 16(2), 197-210. https://doi.org/10.2167/jost738.0

[9] Barber, N. A. (2012). Profiling the Potential "Green" Hotel Guest: Who Are They and What Do They Want? Journal of Hospitality \& Tourism Research, 38(3), 361-387. https://doi.org/10.1177/1096348012451462

[10] Dolnicar, S., \& Grun, B. (2008). Environmentally Friendly Behavior: Can Heterogeneity Among Individuals and Contexts/ Environments Be Harvested for Improved Sustainable Management? Environment and Behavior, 41(5), 693-714. https://doi.org/10.1177/0013916508319448

[11] Panzone, L., Hilton, D., Sale, L., \& Cohen, D. (2016). Socio-demographics, implicit attitudes, explicit attitudes, and sustainable consumption in supermarket shopping. Journal of Economic Psychology, 55, 77-95. https://doi.org/10.1016/j.joep.2016.02.004

[12] Bowker, J. M., \& English, D. B. K. (2002). Mountain Biking at Tsali: An Assessment of Users, Preferences, Conflicts, and Management Alternatives. Gen. Tech. Rep. SRS-59. Asheville, NC: U.S. Department of Agriculture, Forest Service, Southern Research Station.

[13] Han, H., Hsu, L.-T. J., Lee, J.-S., \& Sheu, C. (2011). Are lodging customers ready to go green? An examination of attitudes, demographics, and eco-friendly intentions. International Journal of Hospitality Management, 30(2), 345-355.

[14] Stern, P. (2000). Towards a Coherent Theory of Environmentally Significant Behavior. Journal of Social Issues, 56(3), 407-424. https://doi.org/10.1111/0022-4537.00175

[15] Budeanu, A. (2007). Sustainable tourist behaviour - a discussion of opportunities for change. International Journal of Consumer Studies, 31(5), 499-508. https://doi.org/10.1111/j.1470-6431.2007.00606.x

[16] Juvan, E., \& Dolnicar, S. (2016). Measuring environmentally sustainable tourist behaviour. Annals of Tourism Research, 59, 30-44. https://doi.org/10.1016/j.annals.2016.03.006

[17] Goodwin, H. (2016). Responsible Tourism, Using tourism for sustainable development (2 ${ }^{\text {nd }}$ d.). Goodfellow Publishers Ltd. https://doi.org/ 10.23912/978-1-910158-84-5-3101

[18] Nugraheni, A. I. P., Priyambodo, T. K., Sutikno, B., \& Kusworo, H. A. (2019). Defining social sustainability and socially conscious tourist in sustainable tourism development. Journal of Business on Hospitality and Tourism, 5(2), 264-276. https://dx.doi.org/10.22334/jbhost.v5i2

[19] United Nations Environment Programme (UNEP), \& World Tourism Organization (UNWTO). (2005). Making Tourism More Sustainable: A Guide for Policy Makers. UNEP \& UNWTO.

[20] OECD. (1994). Tourism Strategies and Rural Development. OECD working papers, Vol.2, N.31. Paris: Organisation for Economic Co-operation and Development.

[21] World Tourism Organization (UNWTO) (2019). UNWTO Tourism Definitions | UNWTO Tourism Definitions |Definiciones de turismo de la OMT. UNWTO. https:// doi.org/10.18111/9789284420858

[22] Zhou, L. (2014). Online rural destination images: Tourism and rurality. Journal of Destination Marketing and Management, 3(4), 227-240. https://doi.org/10.1016/j.jdmm.2014.03.002 
[23] SECTUR (2017). Turismo Alternativo: Una nueva forma de hacer turismo. Entorno Turístico. SECTUR.

[24] Saxena, G., Clark, G., Oliver, T., \& Ilbery, B. (2007). Conceptualizing Integrated Rural Tourism. Tourism Geographies, 9(4), 347-370. https://doi.org/10.1080/14616680701647527

[25] Correia, J., Carvalho, P. (2010). Turismo e sustentabilidade do desenvolvimento no contexto das Aldeias Históricas de Portugal. O exemplo do Piódão (Serra do Açor). Proceedings of 16 th APDR Conference, p. 290-318.

[26] Hunter, C. (1997). Sustainable tourism as an adaptive paradigm. Annals of Tourism Research, 24(4), 850-867. https://doi.org/10.1016/S0160-7383(97)00036-4

[27] Robson, J., \& Robson, I. (1996). From shareholders to stakeholders: Critical issues for tourism marketers. Tourism Management, 17(7), 533-540. https://doi.org/10.1016/S0261-5177(96)00070-2

[28] OECD. (2007). Innovative Rural Regions: The role of human capital and technology. The 2007 OECD Rural Policy Conference, Cáceres (Extremadura), Spain.

[29] Luthe, T., \& Wyss, R. (2014). Assessing and planning resilience in tourism. Tourism Management, 44, 161163. https://doi.org/10.1016/j.tourman.2014.03.011

[30] Espiner, S., Orchiston, C., \& Higham, J. (2017). Resilience and sustainability: A complementary relationship? Towards a practical conceptual model for the sustainability-resilience nexus in tourism. Journal of Sustainable Tourism, 25(10), 1385-1400. https://doi.org/10.1080/09669582.2017.1281929

[31] Wang, N. (2020). Construction of the Connotation and Its Theoretical Analysis Framework of Sustainable Development of Rural Tourism in the Context of New Urbanization. IOP Conference Series: Materials Science and Engineering, 750, 012065. https://doi.org/10.1088/1757-899X/750/1/012065

[32] Brundtland, G., Khalid, M., Agnelli, S., Chidzero, B., Fadika, M., Mauff, V. (1987). Report of The World Commission on Environment and Development: Our Common Future.

[33] United Nations World Tourism Organization (UNWTO), \& United Nations Development Programme (UNDP). (2017). Tourism and the Sustainable Development Goals - Journey to 2030, Higblights. UNWTO. https://doi.org/10.18111/9789284419340

[34] Joaquim, G. (1997). Da identidade à sustentabilidade ou a emergência do «turismo responsável». Sociologia - Problemas e Práticas, 23, 77-100.

[35] Bramwell, B., \& Lane, B. (2011). Critical research on the governance of tourism and sustainability. Journal of Sustainable Tourism, 19(4-5), 411-421. https://doi.org/10.1080/09669582.2011.580586

[36] Shedenov, U., Litvishko, O., Kazbekov, B., Suyunchaliyeva, M., \& Kazbekova, K. (2019). Improvement of ecological tourism on the principles of sustainable economic development. E3S Web of Conferences, 135, 04047. https://doi.org/10.1051/e3sconf/201913504047

[37] Wall, G. (1997). Is Ecotourism Sustainable? Environmental Management, 21(4), 483-491. https://doi.org/10.1007/s002679900044

[38] Drumm, A., Moore, A. (2005). Ecotourism Development- A Manual for Conservation Planners and Managers, V.1. An Introduction to Ecotourism Planning, (2 ${ }^{\text {nd }}$ Ed.). The Nature Conservancy.

[39] Ivanov, S. (2010). Ego Tourism. SSRN Electronic Journal, 140-143. https://doi.org/10.2139/ssrn.1537828

[40] He, J., \& Wang, Z. (2020). On Sustainable Development Strategy of Rural Tourism in Jiangxi Province. IOP Conference Series: Earth and Environmental Science, 440, 052094. https://doi.org/10.1088/1755$1315 / 440 / 5 / 052094$

[41] Ribeiro, J., \& Vareiro, L. (2007). Turismo e Desenvolvimento Regional: O Espaço Rural como Destino Turístico. Congresso Internacional "Casa Nobre: Um Património Para O Futuro", Atas do Congresso Internacional". [Arcos De Valdevez]: Câmara Municipal, 2007. pp. 470-486.

[42] Cawley, M., \& Gillmor, D. A. (2008). Integrated rural tourism: Concepts and Practice. Annals of Tourism Research, 35(2), 316-337. https://doi.org/10.1016/j.annals.2007.07.011

[43] Bell, S. and Morse, S. (2003). Learning from experience in sustainability. In: Proceedings International Sustainable Development Research Conference 2003 (Proceedings of), 24-25 Mar 2003, Nottingham, UK.

[44] United Nations. (2007). Indicators of Sustainable Development: Guidelines and Methodologies. 3rd Ed., United Nations.

[45] Toselli, C. (2003). "Turismo cultural, participación localy sustentabilidad". En Análisis sectoriales: Estudio Compartido sobre Turismo y Cultura, Portal Iberoamericano de Gestión Cultural, Universidad de Barcelona, Barcelona. http://www.gestioncultural.org/private/

[46] Ramchurjee, N. A., \& Suresha, S. (2015). Are tourists' environmental behavior affected by their environmental perceptions and beliefs? Journal of Environmental and Tourism Analyses, 3(1), 26-44.

[47] Booking.com. (2019). Booking.com reveals key findings from its 2019 sustainable travel report. 
[48] Wearing, S., Cynn, S., Ponting, J., \& McDonald, M. (2002). Converting Environmental Concern into Ecotourism Purchases: A Qualitative Evaluation of International Backpackers in Australia. Journal of Ecotourism, 1(2-3), 133-148. https://doi.org/10.1080/14724040208668120

[49] Becken, S. (2004). How Tourists and Tourism Experts Perceive Climate Change and Carbon-offsetting Schemes. Journal of Sustainable Tourism, 12(4), 332-345. https://doi.org/10.1080/09669580408667241

[50] Fairweather, J. R., Maslin, C., \& Simmons, D. G. (2005). Environmental Values and Response to Ecolabels Among International Visitors to New Zealand. Journal of Sustainable Tourism, 13(1), 82-98. https://doi.org/10.1080/17501220508668474

[51] UNWTO. (2011b). Conscious Tourism, a proposal of love for life. UNWTO.

[52] UNWTO. (2011a). Conscious Tourism, a proposal to love life. Regional Department for the Americas. UNWTO.

[53] Montesdeoca, E., Rozas, E., \& Roget, F. (2016). Aproximación al «Turismo Consciente», una propuesta ecuatoriana. Congreso Internacional de Turismo Rural y Desarrollo Sostenible, 2016, pp. 567-584. ISBN 978-84-617-5616-2.

[54] Vázquez Rozas, M.E., Montesdeoca, E., Vazquez-Rozas, E., \& Martínez-Roget, F. (2020). «Conscious tourism» from the perspective of experts abstract. HOLOS, 2, 2-21. https://doi.org/10.15628 / holos.2020.5565

[55] United Nations World Tourism Organization (UNWTO). (2013). 2nd UNWTO International Congress on Ethics and Tourism, Quito, Ecuador, September 2012. UNWTO. https://doi.org/10.18111/9789284415212

[56] Abranja, N. A., \& Almeida, I. D. de. (2009). Turismo e Sustentabilidade. Cogitur, Journal of Tourism Studies, 2(2), 15-31.

[57] Dolnicar, S. (2010). Identifying tourists with smaller environmental footprints. Journal of Sustainable Tourism, 18(6), 717-734. https://doi.org/10.1080/09669581003668516

[58] Cooper, G., Green, N., Burningham, K., Evans, D., \& Jackson, T. (2012). Unravelling the Threads: Discourses of Sustainability and Consumption in an Online Forum. Environmental Communication, 6(1), 101-118. https://doi.org/10.1080/17524032.2011.642080

[59] Darnton, A, Verplanken, B, White, P and Whitmarsh, L (2011). Habits, Routines and Sustainable Lifestyles: A summary report to the Department for Environment, Food and Rural Affairs. AD Research \& Analysis for Defra.

[60] Manaktola, K., \& Jauhari, V. (2007). Exploring consumer attitude and behaviour towards green practices in the lodging industry in India. International Journal of Contemporary Hospitality Management, 19(5), 364 377. https://doi.org/10.1108/09596110710757534

[61] Devesa, M., Laguna, M., \& Palacios, A. (2010). The role of motivation in visitor satisfaction: Empirical evidence in rural tourism. Tourism Management, 31(4), 547-552. https://doi.org/10.1016/j.tourman.2009.06.006

[62] Brymer, E., Downey, G., \& Gray, T. (2009). Extreme Sports as a Precursor to Environmental Sustainability. Journal of Sport \& Tourism, 14(2-3), 193-204. https://doi.org/10.1080/14775080902965223

[63] Buckley, R. (2012). Rush as a key motivation in skilled adventure tourism: Resolving the risk recreation paradox. Tourism Management, 33(4), 961-970. https://doi.org/10.1016/j.tourman.2011.10.002

[64] Moral-Moral, M., Renda, A. I., \& Martins, P. (2018). Desenvolvimento turístico sustentável no interior de Algarve (Portugal): O caso da Via Algarviana. Revista Turydes: Turismo y Desarrollo, 24(11), 1-15.

[65] Richards, P., \& Font, X. (2019). Sustainability in the tour operator - ground agent supply chain. Journal of Sustainable Tourism, 27(3), 277-291. https://doi.org/10.1080/09669582.2018.1560451

[66] Fredrickson, L. M., \& Anderson, D. H. (1999). A qualitative exploration of the wilderness experience as a source of spiritual inspiration. Journal of Environmental Psychology, 19(1), 21-39. https://doi.org/10.1006/jevp.1998.0110

[67] Gil, A. (2008). Métodos e Técnicas de Pesquisa Social (6a Edição). Editora Atlas S.A. Instituto Nacional de Estatística.

[68] Johansson, M., Hartig, T., \& Staats, H. (2011). Psychological Benefits of Walking: Moderation by Company and Outdoor Environment. Applied Psychology: Health and Well-Being, 3(3), 261-280. https://doi.org/10.1111/j.1758-0854.2011.01051.x 
[69] Zelezny, L. C., Chua, P.-P., \& Aldrich, C. (2000). New Ways of Thinking about Environmentalism: Elaborating on Gender Differences in Environmentalism. Journal of Social Issues, 56(3), 443-457. https://doi.org/10.1111/0022-4537.00177

[70] World Economic Forum. (2017). Millennials Survey: Refugees Are Welcome, Robots Can't Be Trusted, Climate Change Is Our Biggest Concern'. World Economic Forum.

[71] Barr, S., Shaw, G., Coles, T., \& Prillwitz, J. (2010). 'A holiday is a holiday': Practicing sustainability, home and away. Journal of Transport Geography, 18(3), 474-481. https://doi.org/10.1016/j.jtrangeo.2009.08.007

[72] Masud, M. M., Kari, F. B., Banna, H., \& Saifullah, Md. K. (2018). Does income inequality affect environmental sustainability? Evidence from the ASEAN-5. Journal of the Asia Pacific Economy, 23(2), 213-228. https://doi.org/10.1080/13547860.2018.1442146

[73] Marinao, E. (2018). Determinants of Satisfaction with the Tourist Destination. In Mobilities, Tourism and Travel Behavior. IntechOpen. https://doi.org/10.5772/intechopen.70343

[74] Oliver, R. (1999). Whence Consumer Loyalty? Journal of Marketing, 63, 33-44. https://doi.org/10.2307/1252099

[75] Maroco, J. (2011). Análise Estatística com o SPSS Statistics. 5.th Ed. Edições ReportNumber. 